\title{
Social Justice, Democratic Dialogue And The Quest For National Security: Implications For Sustainable Development In Nigeria
}

\author{
Dr. Daniel Olukayode Adekeye \\ Department of General and Entrepreneurial Studies, \\ Ondo State University of Science and Technology, \\ Okitipupa, Ondo State, Nigeria
}

\begin{abstract}
This essay highlights and examines the political and moral factors embedded in the problem of national security in Nigeria thereby aligning with previous studies which have rejected a pure military approach to issues of security. It discusses the critical socio-political challenges that confront Nigeria in its quest for the establishment of a lasting and genuine national security. The essay examines the connection between security issues and the well-being of the people. It discusses the existential values which are foundational to the establishment of enduring national security in Nigeria. It argues that the nation's aspiration for sustainable development will be realised if the foundation of Nigeria's national security be redefined due to the visible failure of the hitherto restrictive military and economic approaches.
\end{abstract}

Keywords: Democracy, National security, Social justice, Sustainable development

\section{INTRODUCTION}

It is pertinent to set up the flow of the arguments in this paper by briefly underscoring the exact meaning of some of the key terms such as "national security", "development", "sustainable development", "democracy", and "social justice" in the Nigerian context. In this essay, national security is construed and used as the absence of violence whether military, economic, sexual or environmental. It is the assurance of the safety of lives, property, and other social infrastructures that are necessarily required for peace and social order within the context of the nation. It is a conditio sine qua non for the development of the individuals and the nation at large. Development is a continuous process and an unending pathway towards a better livelihood. It is the continuous 'match forward' of the human family towards perfect fulfilment (Ehusani 1991: 244). Development is used synonymously with progress in this paper. In the context of Nigeria, development is construed as the elimination of poverty, disease and ignorance, increase in national wealth in such a way that each person will have enough (Adekeye 2014:105). The paper envisions a systematic transformation of the conditions of life of the majority of people in a beneficial manner to enhance their attainment of individual and collective well-being. Sustainable development is an ethical framework for using the nation's resources efficiently, creating effective infrastructures and relationships, protecting and enhancing quality of lives and creating new business channels to strengthen the economy. Democracy, in the context of this paper is a socio-political paradigm that is constituted by and thrives on free and unconstrained public deliberation of all matters of common concern. By social justice, we refer to a set of principles required for choosing among the various social arrangements which determine the division of advantages and for underwriting an agreement on the proper distributive shares. These principles are the principles of social justice, they provide a way of assigning rights and duties in the basic institutions of society and they define the appropriate distribution of the benefits and burdens 
of social co-operation (Rawls 1972:4). These concepts shall be further elucidated as the arguments and submissions of this essay unfold.

\section{UNDERSTANDING THE IDEA OF NATIONAL SECURITY}

National security is an important concern in the life of a person, group or nation (Ujomu 2001:248). This concern has become all the more important for the people of Nigeria who are constantly bedevilled by several sectarian, religious, ethno-political clashes and terrorist attacks. No wonder it was noted that "in the context of the nation-state, the central feature in the quest for national security is the concern for survival, peace and progress of individuals, groups and the society as a whole" (Ujomu 2001:248). The concern for the security of a nation is undoubtedly as old as the nation-state itself (Brown 1982:21).

National security has been construed in different ways. Brennan (1961:22) holds that national security is the protection of national survival. Ray (1987:248-249) submits that national security is to be understood in terms of the desire and capacity of for self defence. Goldstein (1999:79) conceives national security as closely connected to the preservation of the borders of a state and as mainly construed in terms of the power to maintain a government's sovereignty within its territory. According to Hare (1973:86-89), national security should be understood as the confrontation of threats to peace in the society. The editors of the Africa Research Bulletin (quoted in Ujomu 2001: 248) construe national security in terms of the avoidance of conflicts and confrontations, and the preservation of the lives of people in the society. They perceive national security in terms of the capacity to achieve reconciliation among the diverse groups in the society. More than any of the conceptions of national security highlighted above, the position of the editors of the Africa Research Bulletin addresses the situation of national security in most plural societies.

The socio-political ontology of a multi-ethnic society is such that makes the issue of national security more problematic because there are more tendencies towards contentions than a homogeneous nation-state. For instance, politicians, in the quest for power tend to exploit the ethnic differences for solidarity and patronage. O’Brien (1995: 100) however, asserts a somewhat different idea of national security which he refers to as an inclusive approach to security. Here, security is construed as more than just safety from the violence of rival militaries. It is the absence of violence whether military, economic or sexual. In fact, environmental issues count as security problems (Ujomu 2001:248). In the same vein, MihaiMarcel (2009:117) noted that "the security environment has been changing . . . while the threats are more and more complex and diffuse". Such aspects as environmental degradation, people issues, extreme poverty, disease, unbalance among rich and poor states are vulnerabilities stimulating instability at a local and regional level (Mihai-Marcel 2009:119). Therefore, any discourse that tends to view security in predominantly military or defence terms, will pose a problem for the proper definition of the concept of security (Lodge 1995:316).

It is pertinent to highlight that the contemporary global structure has ensured that there is a new dimension to national security. The speculative studies on the international security environment in the $21^{\text {st }}$ century highlight the fact that the states will have to face numerous armed conflict sources (domestic and foreign), which will challenge the national security resources (Mihai-Marcel 2009:118). However, every nation will have to set its own security strategy based on its own analyses and also on the short, medium and long time security strategy, meant to answer to the citizens' expectations, values, and interests (Mihai-Marcel 2009:118). That is, the responsibility of ensuring the security of a people primarily lies with the national government while the international community is expected to learn support to or 
collaborate with the effort of the home government. Also, the more each state creates its own security strategy, facilities and modern equipment meant to manage the domestic security strategy, the more the collective system is stronger and the common strategy more real and credible (Mihai-Marcel 2009:117). In a nutshell, “...national state always has and always will be the most important player of the contemporary world" (Gratiela \& Constantin 2006:5). This understanding of security and the pivotal role of the national government sets the background for the subsequent development of this paper.

\section{THE PROBLEM OF NATIONAL SECURITY IN NIGERIA: EXPLORING THE POLITICAL AND MORAL UNDERTONE}

Underlying the quest for national security in Nigeria is the issue of political morality, which focuses on the question of defining the relationship between the state and the various groups in the society (Ujomu 2001:245). In his characteristic literary expositions and reconstructions of social realities, Chinua Achebe (1987:141) articulates what he has regarded as 'the prime failure of [the] government', which according to the scholar, is not the massive corruption, nor the 'hand-me-down capitalism', nor the damnable shooting of workers and students. It is the failure of our rulers to re-establish vital inner links with the poor and dispossessed of this country. For Oyeshile, the problem of ethnic cleavages has been a major obstacle to democracy, progress and development in Africa [Nigeria] (2005:18-19). Also, "the lack of national integration is clearly manifested in, among others, the many ethno-religious conflicts of the past three decades, some of which have almost resulted in the collapse of the fabric of society. Yet, without national integration, the socio-economic, political and cultural development of the country and its citizens will remain imperilled" (Abdulrahman 2004:291). Nigeria as a polity has been run as a weakly integrated state in which the affinity and rights of the populace are still hinged on the socially repugnant dichotomy between citizenship and indigeneity (Ayoade \& Oloruntimilehin 2002: 5).

The prevailing situation in Nigeria is largely characterised by widespread mistrust; the social consequences of which Samuel Huntington (1968: 28) remarked as follows:

... the absence of trust in the culture of the society provides formidable obstacles to the creation of public institutions. Those societies deficient in stable and effective government are also deficient in mutual trust among their citizens, in national and public loyalties, and in organization skills and capacity. Their political cultures are often said to be marked by suspicion, jealousy, and latent or actual hostility toward everyone who is not a member of the family, the village, or perhaps the tribe.

Abdulrahman (2004: 292) argues that "at the basis of the perennial conflicts afflicting the nation, the fierce competition for the control of the state, the manipulation of ethnic and religious identities, the clamour for resource control and the convocation of a sovereign national conference, lies the frustration and anger resulting from perceived [and] real inequality and injustice and the failure of the state to generate inclusive growth and development".

According to Ujomu (2001: 249), the prolonged periods of military dictatorship with the attendant economic decay, corruption, abuse of human rights, depreciation of human dignity and general collapse of social infrastructures have ensured that there is a degeneration of the quality of life of the Nigerian people. Consequently, the problem of establishing and sustaining national security in Nigeria is blamed on the "inability of the various governments and state agencies that existed over the decades to ensure the adequate protection, defence, peace, survival, well-being and progress of the citizens, the state and the society at large" (Ujomu 2001: 250). 
The history of the Nigerian state since independence in 1960 has been fraught mostly with regimes (civilian and military) that had very myopic, perverted and unviable ideas of national security. The national security thrust of these regimes focused on the maintenance of personal security and power, to the detriment of the long-term goals of national development and reconciliation (Ujomu 2001: 250). Worse still, in Nigeria, the military which appeared most constitutionally and professionally suited for the task of providing security, has been found deficient as a careful study of their contribution to the history of Nigeria has demonstrated. Therefore, Ujomu (2000: 39) argues that "Nigeria's quest for national security cannot be guaranteed by a large body of security forces, since much of the insecurity, conflicts and crisis that happened in the country from 1960 to 1999, were due to the very actions and omissions of these same security forces". These regimes, like their African counterparts were concerned with consolidating their positions, employing the instruments of ethnicity, religion and clientelism as the tools for dividing the various groups in the society, also engendering factionalism within the Nigerian Armed Forces. This divisive attitude is a confirmation of Luckham's submission that "in most parts of Africa, national security is ideologically constructed through the play of identities and differences within the state as well as in relation to external threats" (1998: 13). Hutchful (1998: 601) submits that the fracturing of the military along ethnic, rank, ideological and generational lines has compromised the objectives of operational efficiency, institutional solidarity and stability of the military as an institution. This failure has resulted in the military's overriding concern for regime and personal security (Amuwo 2000:2).

Still on the failure of the Nigerian security structures to ensure the safety of lives and property, and to ensure peace and stability, Egwu (2000: 4) observed that over the years, the security of the Nigerian nation-state was reduced to that of the ruler and his immediate supporters. Ujomu (2001: 251) noted that evidence of insecurity in Nigeria is the manifest incapability and inefficiency of the police force with its failure to maintain law and order and provide security for the citizens. Regarding the reason for this colossal inefficiency and gross incompetence of the Nigerian security operations, Luckham (1998: 589-592) attributes it to the acts of social banditry, political involvement, corruption, ethnic manipulation and political indoctrination. For Ujomu, "the security calculus of the Nigerian state failed because it did not include vital aspects of social and national development, such as the provision of basic social amenities" (2001: 251).

The implications of the present state of national security in Nigeria include: increasing national decay and insecurity, which is manifest in the regressing economy, unviable health facilities and services, lack of good pipe borne water, weak transportation system, near comatose educational system, fragile financial and economic institutions, pervasive lawlessness, violence and criminality, deteriorating social infrastructures, diminishing standard of living (Nwankpa 2000, Ujomu 2001). The situation of insecurity is clearly seen in the emergence and entrenchment of the ethnic militia such as Oodua Peoples Congress (OPC), Arewa Peoples Congress (APC), the Egbesu boys among others (Ujomu 2002: 205) and the erstwhile NigerDelta militants. These militia groups were formed as a reaction to the real and perceived manipulation of the Nigerian security forces by the ruling class to clamp down on perceived oppositions. These formations suggest that several people [and sub-national] groups are overtly challenging the state authority (Odugbemi 2001: 69) and its capacity to ensure security.

However, the problem of national security, especially in Nigeria, cannot be isolated from the overall moral milieu that has dominated the entire Nigerian social space. Conflicts in Nigeria are created by the problem of socio-economic inequality and poverty, which have been 
aggravated by the attitudes of greed and self-interest that have guided the lives of most Nigerians (Ujomu 2001: 258). Former Nigerian president Olusegun Obasanjo (1999: 8), in the national day speech, emphasised that there is a need to examine the moral foundations of all our actions and to continue to search for the conditions that will make Nigeria a just, free and wealthy society. According to him, for all the social amenities and institutions to be sustainable, they need a fundamental moral reconstruction. This presupposes that a society is as good as the quality of its moral underpinning (Oladipo 2000: 64). According to Ujomu (2002: 205), the absence or lack of operation of some core social values such as trust, cooperation, compassion, justice, tolerance, etc, among the different interests and segments in the society, ensured that the country achieved little or no sustainable development and that the various levels of national government could not effectively manage the nation's resources for the overall security, peace, prosperity and well being of all. Oladipo (2000: 65) maintains that where the moral underpinning is strong and resilient, the society survives and thrives but where it is weak and fragile, the society's capacity for social progress becomes impaired. Considering the high level of corruption perpetuated by public officials in Nigeria - the cases of James Ibori (Wikipedia 2013), Diepreye Alamieyeseigha (Wikipedia 2013) and Halliburton scandal (Omonobi 2012; Wikipedia 2013) are few instances - poor accountability mechanism, the collapse of state institutions such as the security, intelligence services and civil service, electoral fraud and other vices, there is no doubt that Nigeria is more of an example of the latter phenomenon. All of this implies that there is need for an ethical basis for addressing the multi-faceted problems, especially the security challenges of Nigeria.

\section{THE IMPERATIVE OF SOCIAL JUSTICE AND DEMOCRATIC DIALOGUE: ETHICAL FOUNDATIONS FOR NATIONAL SECURITY IN NIGERIA}

The discussion in this section of the paper is premised on the position that identity related or motivated conflicts are possibly the most prevalent single source of insecurity in Nigeria and most of Africa. The defining feature of most plural societies today is the prevalence of social struggles among the various constituent social identities on the one hand and between group identities and the state or government on the other hand. The genocide that ethnic conflicts have produced in Rwanda and Burundi, the confrontation between the state and the religious fundamentalists in Nigeria, Algeria, Kenya and Egypt, the conflicts between the perceived marginalised minority groups and the Federal Government in Nigeria, all these and many others are all about group identity conflicts. Apart from the conflicts in Africa, the upsurge in petty national squabbles after the collapse of the Berlin Wall and the Soviet bloc in 1989 readily come to mind. The implication of these conflicts is the ravaging attack on national security which is evidenced in massive loss of lives and property, a colossal depletion of social order, heated polity and economic turmoil.

Many contributors in traditional or conventional discourse on group conflicts have attempted to reduce it to ethnic conflict, so much so that they viewed all conflicts as a priori ethnic. Owolabi (1999: 155) however argues that this form of analysis is simple and will eventually prevent an appropriate solution. According to him, the divergent group conflicts cannot be subsumed under ethnicity because ethnicity itself in any society is not primordial or innate, but rather fluid and dynamic. (Owolabi, 1999: 156)

The factors that are employed in the mobilization of group solidarity are numerous, and it will be inappropriate to reduce them to ethnicity. Our position is that formation of identities in all societies is motivated by different and multiple considerations, the fundamental reason of which is survival in the face of competition for perceived and real scarce resources. Consequently, the conflicts that emanate in the process of their social relations are majorly motivated by such considerations. In the struggle for resources (economic, political, 
psychological, environmental, etc.), human beings make use of any means depending on its potency to gain advantage. In this sense, the ethnic factor can be used and abandoned depending on its potency and relevance. This accounts for why even ethnicity is a fluid phenomenon, with its boundary shifting based on situations.

Ujomu (2002: 200) identified the problem of resource control as the underlying factor in the establishment and sustenance of the conflict [and insecurity] situation in Nigeria. Underlying the problem of resource control is the phenomenon of marginalization or exclusion. Internal marginalization is the outcome of political, democratic and human development deficits or inadequacies as they prevail within a social system (Ujomu 2002: 200). Internal marginalization is caused by the mismanagement of the economy and the pursuit of a development paradigm that has polarized the different social and economic groups in the society. According to Nolutshungu (1996: 2), the state is central to the process of marginalization, because in so far as states preside over diverse and unequal societies, they simply are not always representative of, or responsive to, all sections of their populations; neither are the interests and concerns of the state always coterminous or congruent with popular interests.

The state as a common political instrument is supposed to be a resource and a resource distributor (Mukherji, 1997: 26), the just management of which will determine its legitimacy. When the state fails to allocate power and distribute resources fairly among the various component social identities, it forfeits its legitimacy. When the "centre can no longer hold", these social identities result to conflicts as they compete for the resources and power to allocate the resources. Gurr in his classic Why Men Revolt argues that groups result to insurrection and challenge the right of the state to the monopoly of legitimate violence when they feel deprived. Groups result to violence only when they feel a sense of relative deprivation. Deprivation means the discrepancy between what people regard as their rights and what they receive in resource distribution by the state. (Gurr, 1970:13) To restore the legitimacy of the state, minimize group conflicts, discourage violence and insurrection, social justice becomes inevitable.

Social justice presupposes a society or a group of people who have rightful claims to common means of livelihood or resources and power to allocate resources. It entails the distribution of material resources and intangible opportunities. The notion of justice is as old as when the civil society came into being. In other words, justice is an ideal that is associated with civility. The point is that the question of justice is only meaningful and relevant within an organized system of human relations. Justice is the idea of giving each person his or her fair due as a matter of right and duty according to an impartial system, bearing in mind the interest of all. Therefore, a claim that injustice has been done implies that some people have received less than their fair share while others have more than their fair share. It also implies that the procedure of distribution itself has been unfair, or that perhaps the whole system is biased in the interest of some, while pretending to serve the interests of all. However, it should be noted that impartiality does not imply treating everyone the same, as this can lead to injustice. Rather, impartiality requires equal consideration of each person without arbitrary prejudice. Reasons must be given for treating people unequally. In the light of this, various theories of justice determine which reasons are relevant in each situation. Each theory of justice, such as "justice as fairness" (Rawls, 1972: 71), and "entitlement theory" (Nozick, 1974: 24) offers its account of what justice requires, and for the inconsistency that each theory bears to the other, the idea of justice becomes a problem in political philosophy. 
The problem with the concept of justice begins with the very meaning of the term. Although, most authors assert that they use it to designate a virtue, but most of the descriptions they attach to it suggest impersonal states of affairs. They ascribe the term not to individuals but to social systems. Nielsen's conception of justice is an indication of the above observation. According to him, the question of justice is the question of what is a proper social order, which can guarantee human flourishing (Nielsen, 1996: 81). This means that a definition of social order is inclusive of a conception of justice. For Ujomu, the idea of justice encapsulates every aspect of institutional rules and relations, which are subject to potential collective decision (Ujomu, 2002: 225). There is such a consideration of the social systems because the individuals mainly operate within the limits of the social structure in which they are situated.

Moreover, the dispensation of justice has been implicated for the various conflicts that have ravaged various societies. Consequently, effective consideration of these conflicts, which constitutes a part of the enterprise of political philosophy, requires a deeper understanding of the idea of justice as it relates to the social structures that breed and sustain these social conflicts. Hence, we observe with Mitchell (1996: 42) that a conflict at any level in society usually involves a struggle for justice. Therefore, we submit that justice, as a social ideal is the fundamental principle of the existence and coexistence of man as well as of human communities, societies and peoples (Pazhayampallil, 1995: 876). The best condition for social order, as diverse social thinkers have argued is the situation where justice is persistently sustained.

Justice is an instrument of legitimation since the state survives and commands obligation depending on its capacity to sustain social justice. Hence, Rawls following Aristotle declares justice as the highest virtue of a society (1972: 71). Rawls defines justice as:

A set of principles required for choosing among the various social arrangements which determine the division of advantages and for underwriting an agreement on the proper distributive shares. These principles are the principles of social justice, they provide a way of assigning rights and duties in the basic institutions of society and they define the appropriate distribution of the benefits and burdens of social cooperation. (1972: 4)

The above remark underscores the importance of justice in building a cohesive and secure society, the kind of society where rights and duties, benefits and burdens are shared in a manner that all parties and different identities are fairly treated. Social justice in relation to social organization also refers to the manner of distributing resources and power. For Otakpor, Justice is the web which holds any society together, like a spider's web it is very fragile. It needs to be handled with care, devotion and dedication. Though fragile, the entire society reverberates whenever (and for whatever reason) a part of this most fundamental societal web is dislocated, punctured or ruptured. In any society where this has been the case, peace, order, unity and stability mean nothing in real time. Consequently, the first and the only known panacea for chaos is the uncompromising pursuit of justice. (1994: 17)

The above passage aptly captures the fundamental role that social justice plays in managing the problems of social identity and national security. Social justice remains a primary consideration in creating and sustaining not only a peaceful relationship between social groups but in affirming the sense and consciousness of dignity and humanity of all the parties to the social structure. Hence, Rawls' conception of justice is geared towards the realization of a well ordered society which can only be attained if its social justice is so designed that the 
subscription to it is stronger and more likely to override disruptive inclinations and differential loyalties.

To this end, the distribution of rights should be effected with fairness, such that all free and rational persons would accept it in a position of neutrality. The ideas of freedom, rationality, equality and neutrality which are the cardinal features of Rawlsian theory of justice seek to ensure that all members of the society are morally obliged to support the society.

The distributive conception of justice has been prevalent in the history of political philosophy. Contemporary theories of justice are dominated by a distributive paradigm, which tends to focus on the possession and allocation of material goods and social positions. Distributive issues are important, but the scope of social justice goes beyond them to include the political, that is, all aspects of institutional organization. In this sense, the concept of justice is coextensive with the socio-political. Roberto Unger (1987: 145) defines politics as "struggle over the resources and arrangements that set the basic terms of our practical and passionate relations. Preeminent among these arrangements is the formative institutional and imaginative context of social life". This predominant focus on the distribution of wealth, income, and positions ignores and tends to obscure the institutional context within which those distributions take place. Hence, a theory of justice should go beyond distribution itself to conception and creation: the naming of the goods, the giving of meaning and the collective making. (Walzer 1983: 7)

This prerequisite for a just social order which includes the extensive conception, creation, shaping and determination of what is just and good is a product of democratic dialogue. Human life is fundamentally dialogical. Human identity achieves fullness in the person's interaction with the world and with other human beings. This dialogical character, which implies a mutual interdependence, is not antithetical to one's ability to achieve individuality, but is rather a crucial aspect of it. The problematic of a multicultural world is not that there is a multiplicity of worldviews, perspectives and moral standpoints, but that all these continue to exist separately and in a state of tension. Therefore, the central challenge for realizing the ethical conditions necessary for national security in Nigeria lies in the capacity to understand and confront the task of managing the nation's pluralism, in order to establish and sustain a stable and prosperous country.

The concept of democracy is elusive. Many scholars who have tried to define this concept have confessed their inability to give an encompassing definition. The popularity of this concept has made virtually all political systems claim to have something to do with democracy or to be driven by democratic ideals. One could argue therefore that "the promotion, practice and vicissitudes of democracy in different parts of the world have exposed it to some definitional haze and diverse forms of interpretations" (Adediran, 1996: 47). Two reasons have been identified for this popularity: first, "democracy has become in current usage, another word for political decency and civilisation" (Owolabi, 1999:5). It is an idea that has become a moral concept thereby drawing the patronage of various regimes that proffer it more for the sake of survival than true commitment to its ideals. Second, democracy has assumed an ideological connotation. For example, the ideological tussle between the socialists and capitalists has generated a situation in which regimes become tagged democratic not necessarily because of its participatory tendencies but mainly due to its ideological persuasion. Therefore, it becomes difficult to present a definition of democracy which can be called objective (Oyekan, 2009: 215). 
It is observed however, that the fundamental explanation of the problem attending attempts at defining democracy is that people tend to confuse 'democracy' as an idea to be appreciated in its etymology with a variety of practical institutional social-translations of this concept. Therefore, it is suggested that to avoid this predicament, any attempt at defining the concept must always take into consideration the etymology of the concept of democracy. (Owolabi, 1993: 113)

Etymologically, "democracy" as a concept in the Greek language is a combination of two words: demos and kratia which means power or sovereignty in the hands of the people. "Democracy" from its Greek origin means the government of the people. Therefore, the only means by which we can adequately define the concept is not to lose sight of this etymology of the concept of democracy as the government of the people. The concept of democracy, in its classical sense goes beyond a form of government; it is a "way of life". Democracy is not all about a system of government where a variety of organizations and associations that are relatively independent in relation to the government and to one another exist (Dahl, 1987: 167). Moreover, it is not a system where the principal leaders are selected through a competitive electoral process in which the majority of the population has the opportunity to participate. These conceptions of democracy are inadequate as they emphasize not only elections but also the elitist character of democratic system. The legitimacy of democracy must be thought to result from the free and unconstrained public deliberation of all matters of common concern (Benhabib, 1994: 26).

Democracy is much more than a form of government or a set of legal arrangements. According to Dewey, democracy should not be conceived as "something institutional and external" but should be seen as a "way of personal life" (Dewey, 1988: 226) that requires "faith in the capacity of human beings for the intelligent judgement and action if proper conditions are furnished (Irele, 1998:14-15, Rockefeller, 1992: 175). Dewey's conception of democracy was born out of a pragmatic everyday experience of neighbours and friends coming together to converse freely with one another. According to him, intolerance, abuses, calling of names because of differences of opinion about religion or politics... as well as because of differences of race, color, wealth or degree of culture are treason to the democratic way of life. He argues that anything that hinders dialogical communication engenders "antagonistic sects and factions and undermines democracy" (Dewey, 1988: 230).

The focus of this paper is the political manifestation of the idea of democracy. Oyekan (2009: 217) has identified basic features of a democracy which include: the legitimacy of authority which emanates from the people either directly or indirectly, the rule of law, individual autonomy, respect for personal and group rights, and the power of the governed to withdraw authority from incompetent governments.

Looking at the above features critically, they represent a more political manifestation of the spirit of democracy that Dewey talked about. On the basis of these features, one can estimate that democracy is a political arrangement in which those who rule do so on the basis of the consent of the governed, while the rulers reciprocate by being accountable to those who bequeath the mandate to them (Owolabi, 1993: 114). It could also be argued, on the basis of the highlighted features that the democratic society allows for individual autonomy and openness; attributes which are very essential for dialogue and dissent communication.

Democracy requires more than institutional guarantees of rights but requires a consistent belief in the possibility of resolving disputes and managing differences through rational deliberation. Undistorted communication is vital in a democratic setting in which there is a cooperative undertaking (Irele, 1998: 15), instead of having a dominant group suppress the 
other through either subtle or evident violence or through intimidation. In the absence of such a cooperative undertaking, the dialogic communicative democracy becomes impossible. Democracy becomes very expedient in multicultural societies such as Nigeria because it caters for diversity and difference of opinions. This expression of difference is not only a right of other persons that must be guaranteed but it also enriches others' life-experience. Democracy relies on the dialogical process as the source of authority and the means of choosing among competing alternatives. What emerges from the above conception of democracy is that democracy entails a socio-political space where there is an unconstrained participation of all citizens in a free and rational public debate which could only take place in the public sphere.

Hence, there is a nexus between democracy and a vibrant public sphere where there is a deliberation on all issues of social relevance in which the citizens can participate. According to Durkheim, democracy lays emphasis on submitting a greater number of things to collective debate and strives as well to achieve a critical consciousness of itself (Durkheim, 1957: 89). This includes the citizens' role in scrutinizing government activities, debating current events in the public sphere. The citizens' capacity to participate in the state's judgement becomes the hallmark of democratic dispensations.

Democracy becomes highly relevant and important in pluralistic societies because it brings about the proper management of diversity and a synthesis of differences in opinion, beliefs and ideals. In democracy, we require real participatory structures in which actual people, with their geographical, ethnic, gender, and occupational differences, assert their perspectives on social issues within institutions that encourage the representation of their distinct voices (Marion 1990: 116). In the context of Nigeria, General Ibrahim Babangida argues that it is this inability to have the requisite democratic attitudes that constantly gives rise to the series of policy failures and what can be called "executive paralysis" (1991: 67).

In a plural society, the civic public does not imply that citizens should be alienated from their particular group affiliations, histories, and needs. Rather, the society should be conceived as an emanation of a complex synthesis of ideas, beliefs, and convictions of diverse groups and orientations. The community is not a given; it is consciously worked out, and in the same manner sustained. The community is basically established around a common goal and a shared aspiration. In many cases, different social identities form an alliance to pursue their perceived common goal. These social identities must appreciate and respect the differences of each other to ensure a community in the real sense. Each social identity should be allowed to locate the common goal within her respective context. This implies that each social group is given the opportunity to express herself within the commonwealth of groups in the pursuit of the common good. The community is not a space for discord, hence it is an essential aspect of the community to harmonize and synthesize the differences of the component identities in their sincere pursuit of the good of all. The community is not an entity; rather it is a relationship that requires the active participation of all the parties to the relationship. The community could be realized and sustained if the component identities could express their differences to the common goal, which is communally pursued.

\section{THE IDEA OF SUSTAINABLE DEVELOPMENT: THE VISION FOR NIGERIA}

It will be difficult to define or impossible to describe everything that the concept "Development" could mean or imply in a single essay as this. Development is a many sided process. At the individual level, it implies increased skills and capacity, greater freedom, creativity, self discipline, responsibility, and material well-being (Walter 1982: 3). The development of the individual is largely a product of the public or collective conventions and world-view of the social group in which a person is accommodated (Adekeye 2013: 87). This is 
because, he is 'socialised' into a social group, and his development is the degree to which he has or he is capable of internalising these communicated norms. The individual is not an isolated island; therefore the indices of individual development highlighted above are expressions that exist in interpersonal relations whose "language game" is a structure put in place by the society. That is, the development of the individual is largely dependent on the extent at which the society enhances such capacities.

At the group level, development implies an increasing capacity to regulate both internal and external relationships (Walter 1982: 3). Development could mean a process of change from one state to the other for the purpose of achieving a goal. It could be the successive stages, landmarks and conditions in the process of realising an end. In characterising development, the latter state is presumably better, higher, more perfect, more complete and advanced than the former. The concept of development is often seen as a derivative of a much older idea of progress, which has its roots going back to ancient Greece.

Today, economic development, that is, the dynamic progression or upward movement in the material welfare of the human person has come to dominate the discursive terrain of development studies (Adekeye, 2014: 110). Economic development is occupying the central position in most developmental concerns and policies. To this effect, consideration for other spheres of human existence is to the extent at which they promote the economy. Hence, development has come to mean: elimination of poverty, disease and ignorance; increase in national wealth in such a way that every person will have enough. The chief aspect of development going by this idea is the degree of access to the wealth of the society and the means of production. It is a systematic transformation of the conditions of life of the majority of people in a beneficial manner to enhance their attainment of individual and collective wellbeing.

However, in pursuit of economic development, man has abused the biosphere, in his way to economic ascendancy; he has violated the peaceful cohabitation of his fellow men (slavery/slave trade, oppression). The blind pursuit of economic growth had brought the current calamitous condition upon man. Environmental degradation, social breakdown, moral decadence, psychological turmoil, cultural dislocation, insecurity and economic depression are few of the problems that threaten the very existence of man. For many Nigerians, the pursuit of economic survival has led to their involvement in crimes such as human trafficking, drug peddling, kidnapping and morally questionable trades such as cyber-crimes, prostitution and ritual killings. In other words, the prevailing hostilities and insecurity in Nigeria are in most instances, expressions of human search for economic gains.

Therefore, the idea of 'sustainable development' was raised as a strategy and process by which communities seek economic development through approaches that also benefit the local environment and quality of lives. It has also become an important guide to many societies that have discovered that traditional development paths are creating, rather than solving societal and environmental problems.

This idea provides a framework, under which communities, states and nations can use resources efficiently, create efficient infrastructures and relationships, protect and enhance quality of lives, and create new businesses to strengthen their economies. The idea of sustainable development is conceived to help create healthy societies that can sustain present generation as well as those that follow via the judicious use of economic, political, environmental and cultural resources. The concept of sustainability emphasises the ideas of "directing", "maintaining", and (re)defining a suitable framework for a desired development, 
which will involve the least risk and loss to humanity. Sustainability, the type we envision for Nigeria, requires that the real incomes rise, that educational standards increase; that the health of the nation improves, that the general quality of life is advanced (Pearce 1989: 2). All these benefits are expected to be realised with little or no damage to the potentials of both the present and future generations of Nigerians.

This idea appeals to many Nigerians, especially to those who are bored with yesterday's talk of ever-increasing consumption over time, and to those countries which have seen very little increase in consumption per capital because of population growth, unbalanced urbanisation and accompanying threats to their natural resource endowment (Olav 1991: 67). Development scholars are of the opinion that we can only make limited progress unless we tackle both human and environmental problems, and balance them in a way that integrates economic, social and environmental issues.

\section{A NEW PARADIGM OF NATIONAL SECURITY: BEDROCK FOR SUSTAINABLE DEVELOPMENT IN NIGERIA}

It was posited earlier that any discourse that construes security in predominantly military or defense terms poses a problem for the proper definition of the concept. Also, as Nolutshungu argued, "we need to jettison, or if one may say, demystify the view that national security dictates a hush-hush discourse in which knowledge is mystified in a cult of technical expertise, and public information characterized by selective disclosure" (1996: 3). These fundamental failures come with poor national security strategy and an incompetent national security paradigm. However, the hope of this paper is the establishment of a national security paradigm that can help to achieve the type of social transformation required for stability and progress in Nigeria (Ujomu 2001: 257). The author of this article is convinced that such a security paradigm is not only fundamental to the emergence of the much desired overall development but also inevitable for its sustainability.

The new paradigm of national security will ensure the nation's ability to prevent tension from escalating into armed conflicts, maintaining an atmosphere of stability, preventing chaos and widespread violence, and ensuring the commitment to human rights (Shea 1995: 364-365). This new paradigm is realizable via an ethical redefinition of the conditions of life in Nigeria. Central to the ethical redefinition of the conditions of life in Nigeria is the mitigation of conflicts - created by the problem of socio-economic inequality and poverty, which in turn have been aggravated by the attitudes of greed and self interest that have guided the lives of most Nigerians (Ujomu 2001: 258). Nolutshungu (1996: 14) agrees that the clarification of the issue of values is important in the question of national security. Therefore, the maintenance of security implies the protection and preservation of certain core values. Values are by definition standards that people aspire to live by as guides to their life (Pascah 2011: 777). By their very nature values are transient and complex (Haydon 1997). According to Verma (1991: 532), "the temporal locus of a value system is always the present. . The central reference point of a value system is the individual and the society of today". In light of these congruent positions on values or a value system, this paper argues for a national security paradigm that is driven by a value system that captures the reality of a post-independent, $21^{\text {st }}$ century democratic political dispensation which encapsulates the individual and group interests. Values such as social justice and democratic dialogue among others have been identified and discussed in details earlier.

Talking about what values can achieve, Senator John McCain (2010:10) argued: "It is true that the Berlin Wall fell for many reasons. Economic power had a lot to do with it - for without the combined wealth of the West, we would never have overcome our darkest hours of need. 
Military power also had a lot to do with it - for without the strength to defend ourselves; our dreams of peace would have remained just that. But beyond all of this, what toppled the Berlin Wall was the West's support for all behind the Iron Curtain who struggled for universal human rights". The lesson from this is that military and economic powers without a viable value system are not enough to create a sustainable national security. Ujomu (2001: 260) agrees that Nigeria's quest for national security cannot be attained through the mere consolidation of its military forces. He observes that much of the insecurity, corruption, injustices and anarchy that have occurred in the nation between 1960 and 2000, were perpetrated directly by the security forces through coup d'état, violence, dictatorship, oppression). At the same time, Ujomu (2001: 260 ) noted that mere economic growth or huge financial revenue cannot be the basis for Nigeria's national security. It is the moral repositioning of the Nigerian state, which must affect every segment of the society such as the political leadership, education, industries, all state agencies, commerce, economy, infrastructures and social services, politics, professional groups, etc. that distinguishes the new national security paradigm from the current defective security paradigm in Nigeria.

It should be mentioned here that the new security paradigm is essential for sustainable development which translates into elimination of poverty, disease and ignorance; increase in national wealth in such a way that every person will have enough. It implies the mitigation of endemic corruption, oppression, injustice, marginalization, victimization and dehumanization which constitute the barriers to individual and group access to the wealth of the nation and the means of production. This viable national security paradigm is essential for a systematic transformation of the conditions of life of the majority of people in a beneficial manner to enhance their attainment of individual and collective well-being which is the hallmark of sustainable development goal in Nigeria. The new national security paradigm is expected to be the outcome of a process of critical examination of the socio-political and ethical foundations of national security in Nigeria; and a general commitment to a value system that enhances respect for human life.

\section{WORK CITED}

Abdulrahman, Adepoju. “Colonialism, Development Paths, Globalization and Social Inequality: The sources of social conflict in Nigeria" in Nigeria and Globalization: Discourses on Identity Politics and Social Conflict. Duro Oni, Suman Gupta, Tope Omoniyi, Efurosibina Adegbija, and Segun Awonusi (eds.). Lagos: Centre for Black and African Arts and Civilization, 291-326, 2004.

Achebe, Chinua. Anthills of the Savannah. United Kingdom: William Heinemann Limited, 1987.

Adediran, T. "Democracy and the Rule of Law: History, Concepts and Contending Ideas in Nigeria": in Democracy and the Rule of Law. A. Ajomo et al (eds). Lagos; Obafemi Awolowo Foundation, 1996.

Adekeye, Daniel. "Investigating the Ethics of Sustainable Development in Restructuring the World Economic System”. Research on Humanities and Social Sciences, vol. 3(6): 87-95, 2013.

Adekeye, Daniel. “An Alternative Platform for Sustainable Development: A Social-Reform Agenda for Nigerian Intellectuals”. Africa Today, vol. 60 (3): 102-117, 2014.

Amuwo, Kunle. "The Discourse of Political Elites on Higher Education in Nigeria” in The Dilemma of Postcolonial Universities. Lebeau et al (eds.). Ibadan: IFRA/African Book Builders, 1-26, 2000.

Ayoade, J.A. and Oloruntimilehin, B.O. “An Overview of Conflict in Nigeria: 1984-2000”. Research Report. No.47. Ibadan: Development Policy Centre, 2002.

Babangida, I. Badamasi. "The Political Foundations of Democratic Values and Institutions in Nigeria” in For Their Tomorrow We Gave Our Today: Selected Speeches of IBB. Vol. 2, Ibadan: Safari Books Limited 65-72, 1991.

Benhabib, S. "Deliberative Rationality and Models of Democratic Legitimacy”. Constellations, vol. 1(1): 26-52, 1994.

Brennan, Donald. "Setting the goals of arms control" in Arms control, Disarmament and National Security. D.G. Brennan (ed.). New York: George Brazillier, 19-42, 1961. 
Adekeye, D. O. (2019). Social Justice, Democratic Dialogue And The Quest For National Security: Implications For Sustainable Development In Nigeria. Advances in Social Sciences Research Journal, 6(4) 53-67.

Brown, Lester. "An untraditional view of national security" in American defense Policy. Reichart (ed.). Baltimore: John Hopkins University Press, 1982.

Dahl, R. "Democracy” in The Blackwell Encyclopedia of Political Institutions. Bogadanor, Vernon. (ed.). Oxford: Blackwell Publishers, 1987.

Dewey, J. “Creative Democracy: The Task Before Us” in Jo Ann Boydston Later works of John Dewey 1925-1953, vol. 14, Carbondale: Southern Illinois University Press, 1988.

Durkheim, E. Professional Ethics and Civic Morals, Glencoe Ill: Free Press, 1957.

Egwu, Samuel. The Origin, Nature and the Politics of the Niger-Delta Crisis: The consequences of violence on the future youths. A paper presented at a Workshop on the reorientation of Youths/Students for the Cause of Peace and democratic Stability in the Niger-Delta. Akwa-Ibom Uyo, May, 2000.

Ehusani, George. An Afro Christian Vision "Ozovehe”: Toward a More Humanized World, Lanham: University Press of America Inc., 1991.

Goldstein, Joshua. International Relations, New York: Addison Wesley Longman, 1999.

Gratiela, Preda and Constantin Barna. Consideratii privind interesele nationale ale Romaniei, Bucharest: U.N.Ap. Publishing House, 2006.

Gurr, T. Why Men Revolt, Princeton: Princeton University Press, 1970.

Hare, R.M. Applications of Moral Philosophy, Los Angeles: University of California Press, 1973.

Haydon, G. Teaching about Values: A new approach, London: Cassell, 1997.

Hutchful, Eboe. "Military issues in the transition to democracy" in The military and militarism in Africa. A. Bathily (ed.). Senegal: Codesria, 599-617, 1998.

Irele, D. The Public Sphere and Democracy, Ibadan: University of Ibadan, 1998.

John, McCain. "National History and Universal Values: Prioritizing human rights in U.S. foreign policy”. Brown Journal of World Affairs, vol. 16(2): 9-14, 2010.

Lodge, Juliet. "Internal security and judicial cooperation” in The European Community and the challenge of future. Juliet Lodge (ed.). London: Pinter, 315-339, 1995.

Luckham, Robin. "The military militarism and democratization in Africa: a survey of literature and issues" in The Military and militarism in Africa. Eboe Hutchful (ed.). Senegal: Codesria, 1-45, 1998.

Marion, I. Young. Justice and the Politics of Difference, Princeton: Princeton University Press, 1990.

Mihai-Marcel, Neag. "National Values and Interest within Present Security Environment”. Buletin Stiintific, vol. 2(28): 117-121, 2009.

Mitchell, Christopher et al. Handbook of Conflict Resolution: The Analytical Problem Solving Approach, London: Pinter Cassell, 1996.

Mukherji, P. "Class and Ethnic Movements in India: In Search of a Pertinent Paradigm for Democracy and Nation Building in the Third World" in When Democracy Makes Sense. Rudebeek L. (ed.), 1997.

Nielsen, K. “Conceptions of Justice” in Encyclopedia of Government and Politics. Hawkesworth, M. (ed.) vol. 1, 1996.

Nolutshungu, Sam. Margins of Insecurity: Minorities and International Security, New York: University of Rochester Press, 1996.

Nozick, R. Anarchy, State and Utopia, New York: Basic Books, 1974.

Nwankpa, Emeka. “ANBA deplores national decay, insecurity”. The Guardian. Thursday 21 December, 2000.

Obasanjo, Olusegun. "Moral foundations for our polity". The Guardian, Friday 1 October, 1999.

O’Brien, Robert. "International political economy and international relations: apprentice or teacher?" in Boundaries in Question: new directions in international relations. John Macmillan (ed.). London: Pinter, 89-106, 1995.

Odugbemi, S. "Ethnic Nationalism and the Future of Nigeria". Recall: A Chronicle of Nigerian Events, no.2: 66-75, 2001.

Oladipo, Olusegun. "Values and National Rebirth". Recall: A Chronicle of Nigerian Events, no. 1: 64-68, 2000.

Olav, Stokke. Sustainable Development, London: Frank Cass \& Co., 1991. 
Otakpor, 0. "A sense of Justice" in Readings in Social and Political Philosophy. Adeigbo, F.A. (ed.) vol: 2. Ibadan: Claverianum Pres, 1994.

Owolabi, K.A. "If Democracy is the Answer, What is the Problem? Demystifying Democracy for Development in Africa" in Democracy, Democratization and Africa. L.A. Thompson (ed.). Ibadan: Afrikalink, 108-124, 1993.

Owolabi, K.A. "Avoiding Anarchy: Social Conflicts, Social Justice and the Challenge of Social Transformation in $21^{\text {st }}$ Century Africa”. International Journal of African Culture and Ideas, vol. 2(1\&2): 153-167, 1999.

Oyekan, Adeolu. “Democracy and Africa's Search for Development”. The Journal of Pan African Studies, vol. 3(1): 214-226, 2009.

Oyeshile, Olatunji. Reconciling the self with the Other: an Existentialist Perspective on the Management of Ethnic Conflicts in Africa, Ibadan: Hope Publications Ltd., 2005.

Pascah, Mungwini. "The Challenges of Revitalizing an Indigenous and Afrocentric Moral Theory in Postcolonial Education in Zimbabwe". Educational Philosophy and Theory, vol. 43(7): 773-787, 2011.

Pazhayampallil, T. “Justice”. Pastoral Guide, Vol. 1. Bangalore, India: Kristu Jyoti Publications, 1995.

Pearce, D.W. et al, "Blueprint for a Green Economy". A Report for the UK Department of the Environment, London: Earthscan Publications, 1989.

Rawls, J. The Theory of Justice, Massachusetts: Belknap Press, 1972.

Ray, James. Global Politics. 3 $3^{\text {rd }}$ edition Boston: Houghton Mifflin, 1987.

Rockefeller, Steven. "John Dewey, Spiritual Democracy, and the Human Future" in Revisioning Philosophy. James Ogilvy (ed.). Albany: State University of New York Press, 165 - 190, 1992.

Samuel, P. Huntington. Political Order in Changing Societies, London: Yale University Press, 1968.

Shea, Jamie. "Security: the future" in The European Community and the Challenge of the Future. Juliet Lodge (ed.). London: Pinter 360-376, 1995.

Ujomu, Philip Ogo. "Ethics and National Security in Nigeria: Critical issues in the search for sustainable development”. The Voice. Millennial edition, Ibadan: Ss Peter \& Paul Seminary, 38-40, 2000.

Ujomu, Philip Ogo. "National Security, Social Order and the Quest for Human Dignity in Nigeria: Some Ethical Considerations". Nordic Journal of African Studies, vol. 10(2): 245-264, 2001.

Ujomu, Philip Ogo. "Social Conflicts, Resource Distribution and Social Justice in Nigeria”. Journal of Asian and African Studies, vol. 63:197-228, 2002.

Unger, R. Social Theory: Its Situation and Its Task, New York: Verso, 1987.

Verma, R.K. "The Concept of Progress and Cultural Identity" in Culture and Modernity. East-West Philosophical Perspectives. E. Deutsche (ed.). Honolulu: University of Hawaii Press, 1991.

Walter, Rodney. How Europe Underdeveloped Africa, Washington D.C.: Howard University Press, 1982.

Walzer, M. Spheres of Justice, New York: Basic Books, 1983.

Wikipedia, The Free Encyclopedia. N.d. Diepreye Alamieyeseigha: Corruption Charges, http://en.wikipedia.org/wiki/Diepreye_Alamieyeseigha (accessed 13 September 2013).

Wikipedia, The Free Encyclopedia. N.d. James Ibori: Corruption Charges, http://en.wikipedia.org/wiki/James_Ibori (accessed 13 September 2013).

Wikipedia, The Free Encyclopedia. N.d. Halliburton: Controversies, http://en.wikipedia.org/wiki/Halliburton (accessed 13 September 2013).

World Bank. 1996. Towards Environmentally Sustainable Development in Sub-Sahara Africa: A World Bank Agenda. Washington D.C. 